\title{
National identity in the discourse of political elites of Poland and Hungary
}

\section{НАЦІОНАЛЬНА ІДЕНТИЧНІСТЬ У ДИСКУРСІ ПОЛІТИЧНИХ ЕЛІТ ПОЛЬЩІ Й УГОРЩИНИ}

Received: March 10, 2021

\begin{abstract}
The article analyses the position of the political elites of Poland and Hungary, who see the strengthening of European integration processes as a threat to national sovereignty and national identity. The authors link the emergence of interest to the problem of the crisis of national identity with the intensification of the activities of right-wing political parties and movements in these countries, which are trying to introduce the idea of right-wing populism into the public consciousness. The beliefs about the unity of society and the revival of traditional values form the basis of right-wing populist ideas. The methodological basis of the study was the comparative method and framing analysis. The comparative method allowed comparing the political rhetoric of the elites of Poland and Hungary, and with the help of framing analysis, the essence of the problem of the crisis of national identity was specified by highlighting its basic parameters. It is proved that the sociopolitical discourse around the problem of national identity has some differences in these countries. This is due to the historical and cultural background of these countries. It is emphasized that right-wing populist parties and movements offer certain ways to respond to the problem of loss of national sovereignty and national identity, namely the consolidation of society based on cultural and religious values, strong advocacy of state interests in the EU structures, pressure on the EU within the Visegrád Group, and others. The authors believe that the broad socio-political discourse on the problem of national identity is a manifestation of "identity politics". It aims to introduce desirable
\end{abstract}

Accepted: April 30, 2021

\author{
Written by: \\ Liliia Khorishko ${ }^{1}$ \\ https://orcid.org/0000-0002-0618-976X \\ Natalia Horlo ${ }^{2}$ \\ https://orcid.org/0000-0003-0872-9333
}

\footnotetext{
${ }^{1}$ Doctor of political sciences, associate professor of the Department of Political Science, Zaporizhzhya national university, Ukraine.

${ }^{2}$ Doctor of political sciences, associate professor of the Department of Political Science, Zaporizhzhya national university, Ukraine.
} 
assessments of the political situation and to implement traditional collective values and vision into the public consciousness by rightwing populist political parties and movements.

Keywords: national identity, identity politics, political elite, political rhetoric, frame.

\section{Introduction}

The integration and globalization processes that became widespread in the twentieth century have significantly changed the world. Nation-states lost the role of the only actors in the world political process because of two reasons. On the one hand, the formation of supranational organizations witnessed the entry of other influential participants into the world political arena, and, on the other hand, simultaneously with the strengthening of global trends, local movements intensified, which was reflected in the concept of "globalization". These processes have affected the state of identities that are in a state of crisis and even in conflict with each other. In particular, the role of regional and ethnic identities has increased with the simultaneous crisis transformation of the role of national identity. This problem was especially acute in Central and Eastern Europe at the beginning of the twenty-first century, when deepening integration into a single political and economic community raised fears among political elites about its threat to national sovereignty and, consequently, national identity. Therefore, political elites, emphasizing the crisis of national identity, try to introduce into the public consciousness their vision of the situation and convince the public of the legitimacy of their political course. The socio-political discourse around the problem of the national identity crisis, initiated by the political elites of Poland and Hungary, is quite illustrative.

\section{Theoretical framework}

Identity as a scientific category means the feeling of belonging of an individual to a community. Each person has a complex hierarchical identification system, in which the national, or civic, identity occupies a prominent place. The phenomenon of national identity, which is considered by scholars in the context of the nation, has been addressed by many researchers, including B. Anderson (2006), E. Gellner (1987), R. Brubaker (1996), J. Habermas (1992), E. Erickson (1968), E. Smith (1991) and others. впровадження правопопулістськими політичними партіями та рухами у суспільну свідомість бажаних оцінок політичної ситуації, актуалізація традиційних колективних цінностей та бачення однакових пріоритетів розвитку національної спільноти.

Ключові слова: національна ідентичність, політика ідентичності, політична еліта, політична риторика, фрейм.

In particular, E. Smith believes that national identity necessarily implies a sense of political community. He singled out the main features of national identity: 1) historical territory or native land; 2) common myths and historical memory; 3) common mass, public culture; 4) uniform legal rights and obligations for all members; 5) common economy with the ability to move within the national territory (Smith, 1991). The role of national identity is huge, while it is the key to social unity. In the modern world, there is a kind of renaissance of nationalism and, accordingly, the importance of national identity is only growing. R. Brubaker quite rightly noted that in the late twentieth century instead of the expected decline of nation-states, there was a revival of nationalism. He singled out a "related series" of modern forms of nationalism, namely: "nationalization" - the nationalism of the titular nations of new or reformed states; cross-border, conducted by the external national homeland; the nationalism of national minorities (Brubaker, 1996).

In the context of democratization of society in multinational states, the solidarity of society can be ensured by a political nation as a union of all citizens based on democratic values and freedoms. The political, or civic, model of the nation comes from France, where the formation of a political nation around the values brought by the revolution, namely freedom, equality, and brotherhood began starting from the end of the eighteenth century. In understanding the essence of the nation and nationalism, we support the modernist approach, represented by such authoritative scholars as B. Anderson (2006), E. Gellner (1987), H. Kohn (1965). According to modernism, nationalism, nations, and nationstates are products of the Modern era, and this very order of appearance of the mentioned phenomena is important. Nationalism, as emphasized by V. Malakhov, performs two main functions - mobilizational and compensatory. Nationalism is resorted to either mobilize the masses to fight an external or internal enemy 


\section{AMA}

(whether real or imagined) or to compensate for some collective trauma. Functions are interconnected - nationalism heals collective trauma only when it manages to consolidate the population around the solution of some common problem (Malakhov, 2005).

In sharply fragmented societies, the core of national identity should be equally formed both on a set of socio-cultural factors, namely language, history, culture, and on socioeconomic factors, i.e. living standards and opportunities for self-realization. Although socio-cultural factors seem quite contradictory, at least given the presence in the state of several regional versions of the historical process, the nation-state, in order to emphasize its cultural and historical uniqueness, must form the cultural core of national identity. One of the tools is the setting of significant "sites of memory" according to the French historian Pierre Nora, these are actualized events and historical characters around which society can unite (Nora, 1984). Of course, it is necessary to choose compromise "sites of memory" that will be perceived by the whole society. In some cases, it is necessary to resocialize individuals who are carriers of archaic identities.

Modern states, which have "schisms" along the lines of "East-West" or "North-South", in the process of building a political nation need to address the complex issue of consensual coexistence of different types of identity, including national, ethnic, regional. If national identity is focused on collective values, then regional identity is often based on the narrow interests of the regional community. At the same time, it is the national identity that is one of the basic components of national security. It can protect the state from centrifugal tendencies. However, in the context of strengthening integration processes, there is a crisis of national identity, which manifests itself in certain disorientation of the individual to its content. This is due to the conflict of values, offered by the supranational community, with the national values. S. Rostetska notes that identity as a problem arises during changes, in a situation when it is necessary to combine new synthetic identities with traditional "self-evident" identities, to create a new socio-cultural collective "I", such as a nation-state (Rostetska, 2018).

The problem of the crisis of national identity and the conflict of identities in general can be solved by conducting an "identity politics". The modern political process is becoming technological, as evidenced by the implementation of identity politics in many modern states. In the social sciences, the constructivist paradigm is becoming widespread, according to which any identities can be constructed. Traditionally, the term "identity politics" is associated with the activities of politicians to develop an identity, although the scope of this concept is much wider. The classification of forms of identity by M. Castells helps to understand identity politics as the activity of political elites. He singles out several forms of identity, namely: 1) legitimizing, which is introduced by the ruling institutions to expand and rationalize their domination; 2) the identity of resistance, which is formed by actors who are in a situation of underestimation; 3) projective identity, in situations where social actors based on available cultural material build a new identity that changes their position in society and aims at transformation of the entire social structure (Castells, 2004).

However, some scholars disagree that the term "politics" in this context should be associated with the action of political elites. Thus, O. Filippova and Yu. Soroka note that the concept of "identity politics" came from the English language, and distinguish between the concepts of "politics" as a process by which groups of people participate in decision-making, and "policy" as a mechanism for achieving goals. Politics as a process is always "subjective" and involves the active position of social actors, who themselves initiate certain actions. Policy as a mechanism dictates for social actors the role of "passive consumers", who are "imposed" from above, the method to achieve their goal. To determine the essence of identity politics, the authors choose the first approach, thus emphasizing the subjectivity of identity politics (as actively transforming properties and abilities of social actors) (Filippova \& Soroka, 2009).

The understanding of identity politics as a social practice dates back to the 1960s in the United States when the government started to take into account the interests of ethnic minorities who had been discriminated against in the previous period of history. C. Hayes notes that identity politics started with the analysis of forms of minority repression in order to make recommendations for rehabilitation, rethinking the place and role of previously humiliated groups in society (Hayes, 2002). The formation of the American nation was the result of identity politics in the United States, with its representatives sharing common values and attitudes. Nevertheless, identity politics is able to "function" also in European continental 
political systems, which are characterized by the presence of many ethnic and cultural segments, which is why the implementation of identity politics in Western countries has become the practice of multiculturalism.

Based on the American experience of identity politics, it is seen as a process of making political decisions about certain acts, actions, policies based on the affiliation of certain individuals to a particular national, ethnic, racial or any other group (Tyshchenko \& Gorobchyshyna, 2010). That is why it is justified to consider identity politics as policymaking with an account of the interests of a particular community.

However, this interpretation somewhat narrows the understanding of identity politics, as it does not take into account the subjectivity of the identity carrier itself, but only considers it as an object of state policy. As L. Nagorna rightly remarks, "the term 'identity politics' is ambiguous, but it is mainly understood as a new dimension of identification practices, the content of which is the conscious construction of identification models depending on the interests and political preferences of elites" (Nagorna, 2008). Successful objects of "reformatting" are regional and national identities, as their carriers are more in line with the characteristics of "imaginary communities" described by B. Anderson (Anderson, 2006). They are created as a result of the identification of the individual with this community on the basis of ideas about the common origin, its mission, values, significant differences from other communities of the same type. The content of these identities largely depends on the interests of political elites. Ethnic identity is a stable entity that is difficult to transform.

The policy of national identity in the conditions of modernization of the political system deserves special attention. The processes of modernization of political systems are gradually covering more and more countries around the world. At the present stage, modernization as a transition from traditional to modern societies in many countries proceeds through democratization. It involves the expansion of forms of participation of individuals in socio-political processes and the formation of new channels of social mobility. Given the growing role of civic participation in the transformational changes, an important condition for effective modernization is the consideration of identity as a factor associated with the self-identification of an individual with a community and based on the perception of collective values and the same priorities for community development.

\section{Methodology}

The use of the comparative method contributes to the expansion of the boundaries of scientific research based on a clearer understanding of the common and special in the studied political phenomena and processes. According to American scholars G. Almond and G. Powell, the comparative method allows to describe and qualify, organize and explain the various scenarios of events occurring in the political sphere of different states (Almond \& Powell, 1984).

The use of framing analysis can help to expand the possibilities of studying current identity problems and the peculiarities of their impact on the functioning of modern political systems (Makarova, 2019). According to I. Goffman, frames allow a simplified interpretation of the content of socio-political situations and the activities of actors interested in its development. In this context, frames are aimed at forming a certain explanation of socio-political reality, personal or collective identification with the situation, awareness of its significance and the need to adapt to existing changes (Goffman, 2003). According to P. Ibarra and J. Kitsuse, the implementation of framing analysis involves the specification of the following parameters of the problem situation: "threat or disaster", "deprivation of rights or oppression", "loss", "unreasonableness" (Ibarra \& Kitsuse, 2007).

In the political sphere, the construction of frames allows to reveal the content of the current problem, to explain the need to find ways to solve it, and to specify the actions of the subjects.

\section{Results and discussion}

The actualization of the ideas of the struggle for the restoration of national identity in Poland and Hungary is connected with the coming to power and the activities of right-wing populist parties. That is the case of "Law and Justice" in Poland and "Fidesz" in Hungary. The spread of rightwing populist ideas in these countries in CentralEast Europe is due to the following factors: the consequences of post-communist transformation; the presence of a gap between public expectations of democracy and the available results; coexistence of features of participatory and subject political cultures (Oskolkov, 2019). Historical and political features of the formation of these political systems formed fear of losing sovereignty and 


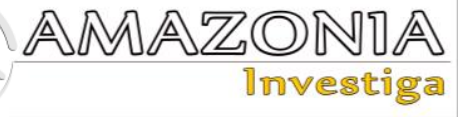

national identity in the public consciousness. This creates additional opportunities for enshrining the following ideas of right-wing populism in the mass consciousness: the canonization of the unity and homogeneity of society; appeals to the right of the majority in case of discrimination against the minority; constructing the image of the enemy (Urbinati, 2014). These ideas underlie the populist rhetoric of the ruling parties (Law and Justice, Fidesz) and their leaders, which calls into question the integrity of the European political and cultural space and threatens the deepening of European integration processes.
The ruling elites of Poland and Hungary constantly emphasize the threat of losing national identity, the gap between national and supranational interests due to EU accession. They are active actors in constructing the framework of the "loss of national identity", which is presented to the public as a pressing issue. Emphasis is placed on finding ways to solve it, which will help to preserve the traditions of state-building and prevent the loss of sovereignty in the context of deepening European integration processes. This is evidenced by the results of the framing analysis of national features of the interpretation of the identity problem, which are presented in Tables 1 and 2.

Table 1.

Framing analysis of the identity problem in Poland.

\begin{tabular}{|c|c|c|c|}
\hline $\begin{array}{l}\text { Frame of } \\
\text { the problem }\end{array}$ & $\begin{array}{l}\text { Interpretation } \\
\text { What is the problem? }\end{array}$ & $\begin{array}{l}\text { Rationalization } \\
\text { Why is this a problem? }\end{array}$ & $\begin{array}{l}\text { Reaction to the problem } \\
\text { What should be done? }\end{array}$ \\
\hline Threat, disaster & $\begin{array}{l}\text { EU intervention in state } \\
\text { sovereignty; imposing a } \\
\text { foreign interpretation of } \\
\text { history; European values } \\
\text { blur the cultural identity } \\
\text { of Poles. }\end{array}$ & $\begin{array}{l}\text { Contempt for Poland's role in } \\
\text { shaping the European political } \\
\text { space; levelling the influence } \\
\text { of the religious factor on the } \\
\text { national consciousness of } \\
\text { citizens. }\end{array}$ & $\begin{array}{l}\text { "The Conservative } \\
\text { Revolution"; strengthening } \\
\text { the influence of religion } \\
\text { and traditions in the } \\
\text { formation of the cultural } \\
\text { space of the state; own } \\
\text { interpretation of significant } \\
\text { events in the history of the } \\
\text { state. }\end{array}$ \\
\hline $\begin{array}{l}\text { Deprivation of } \\
\text { rights, oppression, } \\
\text { discrimination }\end{array}$ & $\begin{array}{l}\text { Ignoring traditional } \\
\text { values reduces the } \\
\text { subjectivity of the state in } \\
\text { shaping historical policy; } \\
\text { uneven distribution of EU } \\
\text { subsidies; labour market } \\
\text { imbalance due to quotas } \\
\text { on migrants. }\end{array}$ & $\begin{array}{l}\text { Narrowing opportunities in the } \\
\text { formation of national historical } \\
\text { policy; reducing the } \\
\text { competitiveness of domestic } \\
\text { producers among other EU } \\
\text { countries. }\end{array}$ & $\begin{array}{l}\text { Strict protection of } \\
\text { national interests; } \\
\text { expansion of social } \\
\text { benefits. }\end{array}$ \\
\hline Loss & $\begin{array}{l}\text { Religious and cultural } \\
\text { identity; influence on } \\
\text { decision-making in the } \\
\text { EU. }\end{array}$ & $\begin{array}{l}\text { Reducing the role of } \\
\text { traditional national values in } \\
\text { the formation of public } \\
\text { consciousness. }\end{array}$ & $\begin{array}{l}\text { Consolidation of society } \\
\text { on the basis of traditional } \\
\text { values; strengthening the } \\
\text { level of identity with the } \\
\text { political system; } \\
\text { glorification of the role of } \\
\text { Poles in history. }\end{array}$ \\
\hline Unreasonableness & $\begin{array}{l}\text { The state has historical } \\
\text { and political traditions of } \\
\text { development, and } \\
\text { therefore should not play } \\
\text { a secondary role in the } \\
\text { European political } \\
\text { process. }\end{array}$ & $\begin{array}{l}\text { Deprivation of Poland of the } \\
\text { role of a leading subject of } \\
\text { European integration } \\
\text { processes. }\end{array}$ & $\begin{array}{l}\text { Formation of the image of } \\
\text { the "great power"; } \\
\text { intensification of activities } \\
\text { aimed at putting pressure } \\
\text { on the EU within the } \\
\text { Visegrád Group. }\end{array}$ \\
\hline
\end{tabular}

Developed by the authors based on: FitzGibbon, J., Guerra, S. (2010), Oskolkov P. (2019).

The obtained results of the research testify active usage of the framing "problem of national identity" by the ruling political elite of Poland in order to influence the formation of the appropriate emotional background of understanding the state and prospects of state development. The focus of public attention on this problem is explained by the following factors: historical and political conditions of formation, development of Polish statehood; recognition of the historical role of religion in state-building processes; dominance in the public 
consciousness of the image of the "great power"; the desire to avoid the status of a peripheral member of the EU; the desire of the ruling elite to expand opportunities for influence and access to resource allocation; the need to legitimize in the eyes of the public the decision to monopolize power and curtail liberal reforms. Right-wing populist rhetoric is actively used in this context, which allows placing the following accents:

1. The ratio of national and European values. Modern European values accumulate new trends in the understanding of marriage, family values, and upbringing of the younger generation, eliminating the influence of religious and national values. Excessive emphasis on the equality of rights and freedoms of citizens leads to an uncontrolled increase in the influence of migrants on the functioning of the political and cultural space of the state, creating problems of the national identity of Poles.
Therefore, a "conservative revolution" is needed, i.e. a return to traditions and religious values that will contribute to the consolidation of citizens in defending national interests.

2. Clear definition of the image of an external enemy. In its desire to deepen European integration, the EU is expanding its decision-making powers. The national elite is gradually losing leverage in domestic and foreign policy, and Poland is losing its subjectivity in European integration processes. This is unacceptable, given the experience and role of the state in the formation of European civilization. Consolidating the efforts of the elite and society will help to defend national interests.

Similarly, a study of the frames of the Hungarian identity problem was conducted, the results of which are presented in Table 2.

Table 2.

Framing analysis of the identity problem in Hungary.

\begin{tabular}{|c|c|c|c|}
\hline $\begin{array}{l}\text { Frame of } \\
\text { the problem }\end{array}$ & $\begin{array}{l}\text { Interpretation } \\
\text { What is the problem? }\end{array}$ & $\begin{array}{l}\text { Rationalization } \\
\text { Why is this a problem? }\end{array}$ & $\begin{array}{l}\text { Reaction to the problem } \\
\text { What should be done? }\end{array}$ \\
\hline Threat, disaster & $\begin{array}{l}\text { EU intervention in state } \\
\text { affairs; economic crisis; } \\
\text { dependence on foreign } \\
\text { investors. }\end{array}$ & $\begin{array}{l}\text { National elite loses } \\
\text { subjectivity in the reform } \\
\text { process; low level of welfare } \\
\text { of citizens compared to other } \\
\text { EU members. }\end{array}$ & $\begin{array}{l}\text { "Economic Liberation War"; } \\
\text { consolidation of society } \\
\text { based on cultural and } \\
\text { religious values; } \\
\text { strengthening of } \\
\text { identification with the } \\
\text { political system. }\end{array}$ \\
\hline $\begin{array}{l}\text { Deprivation of } \\
\text { rights, oppression, } \\
\text { discrimination }\end{array}$ & $\begin{array}{l}\text { Uneven conditions for } \\
\text { receiving subsidies and } \\
\text { funding; IMF } \\
\text { intervention; ignoring } \\
\text { the role of religion in } \\
\text { shaping European } \\
\text { values by the EU; the } \\
\text { impact of migration } \\
\text { processes on the } \\
\text { national unity. }\end{array}$ & $\begin{array}{l}\text { Use of the resource potential } \\
\text { of a state by MNC; weakness } \\
\text { of domestic producers among } \\
\text { other EU countries; change in } \\
\text { the content of family values; } \\
\text { reducing the level of cultural } \\
\text { identification. }\end{array}$ & $\begin{array}{l}\text { Introduction of a tax on the } \\
\text { activities of "big business"; } \\
\text { strengthening the influence } \\
\text { of religious and national } \\
\text { values in the formation of } \\
\text { public consciousness; } \\
\text { introduction of quotas for } \\
\text { migrants. }\end{array}$ \\
\hline Loss & $\begin{array}{l}\text { Deprivation of } \\
\text { sovereignty in } \\
\text { economics and politics; } \\
\text { blurring of national and } \\
\text { religious identity. }\end{array}$ & $\begin{array}{l}\text { MNCs lobby their own } \\
\text { interests, staying away from } \\
\text { state problems; lack of a clear } \\
\text { power vertical; reducing the } \\
\text { importance of Christian values } \\
\text { in the formation of national } \\
\text { identity. }\end{array}$ & $\begin{array}{l}\text { Tax pressure on MNCs; } \\
\text { centralization of power; } \\
\text { strict defence of the interests } \\
\text { of the state; amending the } \\
\text { Constitution on the role of } \\
\text { religion in the formation of } \\
\text { political and national } \\
\text { identity. }\end{array}$ \\
\hline Unreasonableness & $\begin{array}{l}\text { Liberal reforms form } \\
\text { economic dependence; } \\
\text { why fight for } \\
\text { sovereignty if it had to } \\
\text { be given to the EU. }\end{array}$ & $\begin{array}{l}\text { Dependence of state policy on } \\
\text { EU decisions; discrepancy } \\
\text { between EU and national } \\
\text { interests. }\end{array}$ & $\begin{array}{l}\text { Clear awareness of national } \\
\text { interests; strict defence of } \\
\text { country's positions within } \\
\text { EU structures; putting } \\
\text { pressure on the EU within } \\
\text { the Visegrád Group. }\end{array}$ \\
\hline
\end{tabular}

Developed by the authors based on: Lukianov, F. (2017), Orbán V. (2017) 


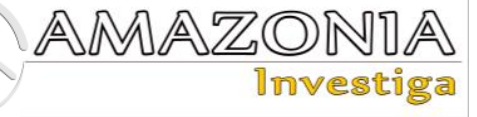

The political elite of Hungary also focuses on the identity crisis but sees it as part of the loss of the country's economic and political sovereignty as a result of EU accession. Right-wing populist rhetoric contributes to the formation of public opinion and the corresponding emotional background of the problem perception. The immediacy of this issue for the public is determined by the influence of the following factors: the complexity of the processes of postcommunist transformation for the political system; the lack of synchronicity in the implementation of economic reforms, which affected their quality; the desire of the ruling elite to expand access to the distribution of resources, especially economic; the increasing pressure and control of the EU institutions over the policymaking process. In this context, the following aspects that reveal the Hungarian peculiarities of the interpretation of the identity crisis can be distinguished:

1. Correlation of national and supranational interests. Liberal reforms increase the state's economic dependence on MNCs and the IMF. Only the conduct of the "economic liberation war" will help to overcome the economic crisis and restore the power of the state. The EU-initiated deepening of European integration processes implies a gradual loss of state sovereignty. Hungary's national interests are formed based on a synthesis of historical (the idea of "Greater Hungary") and religious (Christianity as a state-building factor) traditions. Thus, excessive liberalism in the understanding of rights and freedoms, family values, proposed by the EU harms national interests, disorients Hungarian society, reducing the level of national identity.

2. Creation of the image of an external enemy. The deepening of European integration processes contributes to the excessive bureaucratization of the EU institutions seeking to expand their powers. European directives on tax benefits for foreign capital, the formation of quotas for the admission of migrants do not meet the national interests of the state. The ruling elite of Hungary is committed to "waging war in all directions" to prevent the loss of economic and political sovereignty. The effectiveness of the struggle depends on the level of consolidation of society around national traditions and values formed in the process of state formation.

The results of the study of identity problems in Poland and Hungary indicate the formation of a new agenda by the ruling political elites regarding the content and essence of the European integration process. There is a gradual rethinking of their role and importance in further processes of national state-building. This is due to the impact on the development of the EU of both global (economic crisis 2008-2009, migration crisis 2015) and internal (contradictions and asymmetry in the mechanisms of the euro-zone, excessive bureaucratization in decision-making) crisis phenomena. They hindered the adequate response of the EU management structures to global challenges, which provoked an increase in disintegration trends (Sidenko, 2018).

Poland and Hungary, which in the early 1990s saw European integration as a mechanism for achieving the public good and returning to a European identity, are now the main critics of various EU policies. These states have a significant historical experience of statebuilding, which is closely linked to the formation of the European political space and its values. Thus, contradictions in the understanding of the content of values and subjectivity in decisionmaking are seen as a threat to sovereignty, which requires an adequate response from the national elite. The content of modern European integration processes, according to the ruling elites, provokes crises in the processes of state formation. First, the identity crisis deepens due to the contradiction between new European and traditional national values. Second, the asymmetry in the formulation and implementation of the EU policy towards less developed countries calls into question their subjectivity and sovereignty compared to more developed countries.

\section{Conclusions}

Thus, integration processes today pose new challenges to European states. The political elites in the countries of Central and Eastern Europe are especially sensitive to them, which is connected with the intensification of the activities of the right-wing political parties and movements in these countries. Given the objective difficulties and problems on the path to European integration and seeing European integration as a threat to national sovereignty and national identity, these parties are trying to take advantage of the situation and introduce rightwing populist ideas that emphasize the unity of society and the revival of traditional values. Consequently, the political elites of Poland and Hungary form a "problem of national identity" in public discourse. The framing analysis of the 
problem of identity in Poland and Hungary shows that the problem of the crisis of national identity is interpreted within the concepts of "Threat, disaster", "Deprivation of rights, oppression", "Loss", "Unreasonableness". The political elites of Poland and Hungary emphasize the differences in the political values offered by European integration and national values. Accordingly, ways to overcome the problem are offered in line with populism. At the same time, political elites pursue rational goals, trying to legitimize their actions in the eyes of the public. Differences in the interpretation of the "problem of national identity" in Poland and Hungary are due to the historical and cultural specifics of these countries, in particular, in Hungary, rightwing parties appeal to the revival of the idea of "Greater Hungary". Thus, the discourse of the political elites of Poland and Hungary around the problem of the national identity crisis is a manifestation of "identity politics", as it ultimately contributes to the transformation of national identity.

\section{Bibliographic references}

Anderson, B. (2006). Imagined Communities. London, New York: Verso.

Almond, G. \& Powell, G. (1984). Comparative Politics Today. A World. Third edition. BostonToronto: Little, Brown and Company.

Brubaker, R. (1996). Nationalism reframed: nationhood and the national question in the New Europe. Cambridge: Cambridge University Press. Castells, M. (2004). The power of identity. Malden MA: Blackwell.

Filippova, O.A., \& Soroka, Yu.G. (2009). Identity politics: anthropological methods and sociocultural interpretations. Methodology, theory and practice of sociological analysis of modern society, issue 15, pp. 129-135. Printed edition.

FitzGibbon, J., \& Guerra, S. (2010). Not just Europeanization, not necessarily populism: potential factors underlying the mobilization of populism in Ireland and Poland. Perspectives on European Politics and Society, 11(3), pp. 273-291. Gellner, E. (1987). Culture, Identity, and Politics. Cambridge: Cambridge University Press.

Goffman, I. (2003). Frame analysis an essay on the organization of experience. Moscow, Russia: Institute of Sociology, Russian Academy of Sciences.

Erickson, E. (1968). Identity: Youth and Crisis. New York: Norton, 1968.
Habermas, J. (1992). Citizenship and National Identity: Some Reflections on the Future of Europe, Praxis International, num. 12(1), pp. 1-19.

Hayes, C. (2002). Identity Politics. Stanford Encyclopedia of Philosophy. Retrieved from: https://plato.stanford.edu/entries/identity-politics/ Ibarra, P., \& Kitsuse, J. (2007). Claims-making discourse and vernacular resources. Social problems: a constructionist reading. Kazan, Russia: Kazan University. Retrieved from: https://kpfu.ru/staff_files/F492933121/Social_Prob lems_Constructionist_Reading.pdf

Kohn, H. (1965). Natlonalizm: Its Meaning and History. Princeton, N.J.: Van Nostrand.

Lukianov, F. (2017) Viktor Orban: From ultraliberalism to Euroscepticism. The evolution of the political leader. Urgent problems of Europe. Eastern Europe: Political processes and public sentiment, num. 3, pp. 12-39.

Makarova, T. (2019). Concept «identity» in antique philosophical discourse. Amazonia Investiga, 8(19), pp. 207-211. https://amazoniainvestiga.info/index.php/amazonia /article/view/221

Malakhov, V.S. (2005). Nationalism as a political ideology. Moscow: KSU.

Nagorna, L.P. (2008). Regional identity: Ukrainian context. Kyiv: I.F. Kuras Institute of Political and Ethnic Studies of the National Academy of Sciences of Ukraine.

Nora, P. (1984). Memorial place. Paris: Gallimard. Orban, V. (2017) Battles with Brussels on migration and economic issues are expected. Magyar Hirlap. Retrieved from: https://www.magyarhirlap.hu/belfold/Orban_Vikto r_Migracios_es_gazdasagszervezesi_kerdesekben_ varhatok_csatak_Brusszellel

Oskolkov, P. (2019). RightWing Populism in the European Union. Moscow, Russia: Institute of Europe, Russian Academy of Sciences.

Sidenko, V. (2018) Reformatting European integration: opportunities and risks for the UkraineEU association. Kyiv, Ukraine: Testament.

Rostetska, S.I. (2018). Conflict of identities as a threat to the security of modern states. Current policy issues, issue 61, pp. 128-137.

Smith, A.D. (1991). National identity. London: Penguin Books.

Tyshchenko,Yu., \& Gorobchyshyna, S. (2010). Civil society in Ukraine and "identity politics". Ukrainian Center for Independent Political Research. Kyiv: Ukraine. Retrieved from: http://ito.vspu.net/ENK/Inf_Syspilstvo/sam_rob/1 Sam_rob_/\%D0\%A1_6/\%D0\%A1_6_1/identity20 10.pdf

Urbinati, N. (2014). Democracy Disfigured: Opinion, Truth and the People. Cambridge: Harvard University Press. 